\title{
PENGKONDISIAN SINYAL ELECTROMYOGRAPHY SEBAGAI IDENTIFIKASI JENIS GERAKAN LENGAN MANUSIA
}

\author{
Rizal Maulana ${ }^{1}$, Rekyan Regasari Mardi Putri² \\ ${ }^{1}$ Teknik Komputer, Fakultas Ilmu Komputer, Universitas Brawijaya \\ ${ }^{2}$ Teknik Komputer, Fakultas Ilmu Komputer, Universitas Brawijaya \\ Email: ${ }^{1}$ rizal_lana@ub.ac.id, ${ }^{2}$ rekyan.rmp@ub.ac.id
}

(Naskah masuk: 28 Mei 2018, diterima untuk diterbitkan: 7 Agustus 2018)

\begin{abstract}
Abstrak
Sinyal biomedis merupakan sinyal yang diperoleh dari dalam tubuh manusia yang membawa informasi mengenai gambaran kondisi jaringan atau organ terkait dengan sinyal biomedis tersebut. Electromyography (EMG) merupakan salah satu teknik yang bisa digunakan untuk merekam sinyal biomedis dalam mengetahui informasi dari pergerakan otot lengan. Sinyal EMG menghasilkan sinyal sesuai dengan gerakan yang dilakukan oleh lengan, namun sinyal yang dihasilkan dari elektroda masih tercampur oleh sinyal noise yang dihasilkan oleh beberapa sumber. Akibatnya pendeteksian sinyal EMG menjadi kurang optimal. Untuk mengatasi hal tersebut diperlukan sebuah sistem yang dapat melakukan pembacaan sinyal EMG dan menghilangkan noise yang ada pada sinyal. Pada penelitian ini dirancang sebuah rangkaian pengkondisi sinyal yang terdiri dari penguat instrumentasi, high pass filter (HPF) dan low pass filter (LPF). Rangkaian ini digunakan untuk memproses sinyal yang dihasilkan oleh elektroda yang ditempatkan pada lengan manusia. Hasil dari rangkaian pengkondisi sinyal diproses kembali menggunakan filter eksponensial untuk didapatkan sinyal yang lebih akurat. Sinyal yang telah diproses akan dianalisis besar amplitudonya untuk dapat ditentukan jenis gerakan lengan yang sedang dilakukan. Dari hasil pengujian didapatkan nilai amplitudo rata-rata sebesar $0.166 \mathrm{~V}$ untuk gerakan lengan lurus, $0.588 \mathrm{~V}$ untuk gerakan lengan $45^{\circ}, 1.049 \mathrm{~V}$ untuk gerakan lengan $90^{\circ}, 1.367 \mathrm{~V}$ untuk gerakan lengan $135^{\circ}$ dan $1.647 \mathrm{~V}$ untuk gerakan lengan $180^{\circ}$. Sedangkan untuk akurasi sistem dalam menentukan jenis gerakan lengan, didapatkan nilai akurasi sebesar $86.67 \%$.
\end{abstract}

Kata kunci: sinyal otot, gerakan lengan, electromyography, pengkondisi sinyal, filter eksponensial

\section{ELECTROMYOGRAPHY SIGNAL CONDITIONING AS IDENTIFICATION OF THE TYPE OF HUMAN ARM MOVEMENT}

\begin{abstract}
Biomedical signal is signals obtained from the human body that carry information about the condition of tissues or related organs. Electromyography (EMG) is one method in biomedical field that can be used to record biomedical signal to gain the information about arm muscle activity. The EMG signal generates signals according to the movement performed by the arm, however the signals generated from the electrode are still contaminated by noise signals generated by multiple sources, as a result the EMG signal detection becomes less accurate. To resolve these problems, it is necessary a system that can perform EMG signals detection and remove the noise from EMG signals. In this research, we have designed a signal conditioning circuit consist of instrumentation amplifier, high pass filter and low pass filter. This circuit was used to process signals generated by the electrode placed on the arm. The results of the signal conditioning circuit are reprocessed using an exponential filter to obtain a more accurate signal. The signals that have been processed will be analyzed the amplitude to determine the type of arm movement performed. From the test results obtained average amplitude of 0.166 V for straight arm movement, $0.588 \mathrm{~V}$ for the $45^{\circ} \mathrm{arm}$ movement, $1.049 \mathrm{~V}$ for the $90^{\circ} \mathrm{arm}$ movement, $1.367 \mathrm{~V}$ for the $135^{\circ} \mathrm{arm}$ movement and $1.647 \mathrm{~V}$ for the $180^{\circ}$ arm movement. In addition, the system has an accuracy of $86.67 \%$ in determining the type of arm movement.
\end{abstract}

Keywords: muscle signals, arm movement, electromyography, signal conditioning, exponential filter 


\section{PENDAHULUAN}

Perkembangan penelitian dalam bidang biomedical engineering sangatlah pesat, khususnya dalam bidang pemrosesan sinyal biomedis. Sinyal biomedis merupakan sinyal yang dapat diukur dan dianalisis untuk mengetahui informasi mengenai struktur dan fungsi dari sistem biologis sebuah organ tubuh (Santagati, et al., 2017). Sinyal biomedis terjadi akibat proses fisiologi yang terjadi di dalam tubuh manusia. Dengan menggunakan sinyal biomedis, tidak diperlukan lagi tindakan invasive untuk mengetahui kondisi jaringan maupun organ dari seseorang. Dimana tindakan invasive sendiri merupakan tindakan medis dengan cara memasukkan sebuah alat ke dalam tubuh manusia untuk mendapatkan informasi keadaan organ di dalamnya. Tindakan ini tidak efisien dan memiliki resiko yang sangat tinggi karena dapat merusak rongga maupun organ tubuh manusia (Auricchio, et al., 2017).

Sinyal biomedis yang bisa didapatkan dari dalam tubuh manusia ada beberapa macam, diantaranya yaitu sinyal Electrooculography (EOG) yang membawa informasi mengenai pergerakan bola mata, sinyal Electromyography (EMG) yang membawa informasi dari pergerakan otot lengan, maupun sinyal Electrocardiography (ECG) yang membawa informasi sinyal dari jantung (Hasanah, et al., 2016). Sinyal-sinyal biomedis tersebut tidak hanya dipergunakan untuk mendeteksi adanya gangguan pada jaringan atau organ tubuh manusia, namun bisa juga digunakan untuk memberikan gambaran dari sebuah organ dalam melakukan suatu mekanisme kerja yang dilakukan oleh tubuh manusia. Dengan mengetahui mekanisme kerja dari sebuah organ, informasi yang didapatkan dari sinyal biomedis tersebut dapat digunakan sebagai masukan untuk sistem kontrol sebuah perangkat maupun organ artifisial yang berguna untuk membantu penderita disabilitas (Rajesh, et al., 2014).

Disabilitas merupakan kondisi dimana tubuh seseorang tidak mampu melakukan aktifitas dikarenakan keterbatasan fisik maupun psikologis (Rector, 2018). Keterbatasan ini menyulitkan penyandang disabilitas dalam melakukan berbagai kegiatan. Mereka cenderung memerlukan pertolongan orang lain dalam memenuhi kegiatan sehari-harinya tanpa bisa melakukannya secara mandiri. Berbagai macam cara dilakukan agar taraf hidup penyandang disabilitas diperkuat dan memiliki hak-hak yang sama tanpa diskriminasi apapun (Iskandar, 2012). Salah satunya yaitu dengan memberikan penderita disabilitas sebuah perangkat buatan yang bisa digunakan untuk menggantikan bagian tubuh yang hilang.

Bagi para penyandang disabilitas yang memiliki keterbatasan pada lengan, perangkat lengan buatan (prosthetic arm) merupakan hal yang paling mereka butuhkan. Lengan buatan mempunyai dua fungsi utama, yaitu sebagai tampilan maupun sebagai alat fungsional. Lengan buatan yang berfungsi sebagai tampilan saja, memiliki bentuk yang mirip dengan lengan asli, namun tidak bisa melakukan fungsi sebagaimana lengan asli. Sedangkan untuk lengan yang mempunyai fungsi sebagai alat fungsional, memiliki bentuk berupa lengan robot dan bisa melakukan beberapa fungsi gerakan sebagaimana lengan asli (Jumeno, et al., 2009).

Pergerakan lengan buatan yang berupa lengan robot bergantung dari sinyal masukan sistem, dimana sinyal masukan tersebut digunakan untuk melakukan kontrol motor-motor yang terdapat pada lengan robot. Sinyal masukan ini bisa didapatkan dari pembacaan sinyal EMG. EMG menghasilkan sinyal sesuai dengan gerakan yang dilakukan oleh otot lengan manusia. Namun, sinyal yang dihasilkan oleh EMG tidak bisa langsung diproses, dikarenakan sinyal tersebut masih berupa sinyal mentah yang masih tercampur oleh noise dan perlu dilakukan pengkondisian sinyal (Chowdurry, et al., 2013). Jadi pengkondisian sinyal ini merupakan tahapan yang krusial untuk mendapatkan bentuk sinyal yang sesuai dengan pergerakan lengan manusia.

Penelitian mengenai lengan buatan telah dilakukan oleh Sharmila. Dalam penelitian tersebut, dirancang sebuah lengan buatan dengan menggunakan EMG dan Support Vector Machine (SVM) sebagai metode klasifikasinya. Proses klasifikasi dilakukan di dalam mikrokontroller dan hasil klasifikasi tersebut digunakan untuk memberikan sinyal kontrol sebagai penggerak lengan buatan. Pada penelitian ini didapatkan akurasi sistem sebesar 76.6\% (Sharmila, et al., 2016). Dimana nilai akurasi ini tidak cukup baik dan hal ini dipengaruhi oleh beberapa faktor. Salah satunya adalah sinyal keluaran EMG yang masih belum memberikan akurasi yang optimal dikarenakan adanya noise dan juga proses pengkondisi sinyal yang belum cukup baik.

Pengkondisi sinyal yang diperlukan untuk mengolah sinyal EMG diantaranya yaitu low pass filter (LPF), high pass filter (HPF) dan juga penguat instrumentasi. Namun, pengkondisian sinyal secara hardware saja tidak cukup untuk bisa mendapatkan sinyal EMG yang akurat. Oleh karena itu, perlu ditambahkan pula metode pemfilteran secara software yang sesuai dengan karakteristik noise yang ada pada sinyal EMG. Salah satu jenis filter yang dapat digunakan yaitu filter eksponensial. Seperti yang pernah dilakukan oleh Muchlis dalam penelitiannya yang menggunakan filter eksponensial untuk menghilangkan noise yang ada pada sinyal pergerakan bola mata menggunakan EOG (Muchlis, et al., 2018).

Berdasarkan uraian latar belakang di atas, penelitian ini akan dilakukan dengan fokus pada perancangan pengkondisi sinyal EMG baik secara hardware maupun software. Diperlukan pengkondisian sinyal yang sesuai agar dapat menghilangkan noise yang tercampur pada sinyal EMG. Hal ini perlu dilakukan secara detail sebelum 


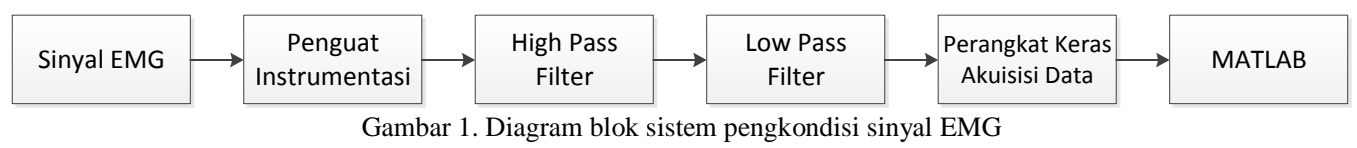

nantinya sinyal dapat diklasifikasikan jenis gerakannya dengan menggunakan metode klasifikasi tertentu. Diharapkan dengan adanya penelitian ini, didapatkan sinyal yang valid sebagai masukan sistem lengan buatan pada pengembangan penelitian selanjutnya.

\section{METODE PENELITIAN}

Tujuan utama dari penelitian ini adalah untuk merancang rangkaian pengkondisi sinyal EMG baik secara hardware maupun software agar didapatkan hasil pembacaan sinyal yang akurat. Sehingga nantinya dapat diketahui bentuk sinyal otot lengan untuk masing-masing gerakan lengan yang dilakukan. Diagram blok dari sistem secara keseluruhan ditunjukkan pada Gambar 1.

Dalam diagram blok tersebut, sinyal EMG didapatkan dari elektroda yang dipasang pada lengan manusia. Sinyal yang dihasilkan oleh elektroda perlu untuk dikuatkan, karena besarnya sinyal tersebut masih dalam orde microvolt. Disini penguat yang digunakan adalah penguat instrumentasi, karena diperlukan sebuah penguatan yang dapat memproses selisih tegangan yang ada pada dua masukan, dalam hal ini adalah dua buah elektroda yang terpasang pada lengan. Setelah itu diperlukan proses filtering dengan menggunakan high pass filter (HPF) dan low pass filter (LPF), dimana HPF dan LPF berfungsi untuk membatasi frekuensi yang dihasilkan oleh gerakan lengan manusia. Karena hanya frekuensi tertentu saja yang berisi informasi penting mengenai gerakan lengan. Filter yang digunakan dalam penelitian ini merupakan filter aktif yang tersusun dari resistor, kapasitor dan op-amp. Baik HPF maupun LPF yang digunakan menggunakan orde 2. Sinyal keluaran dari LPF dihubungkan dengan perangkat keras akuisisi data dan kemudian diproses menggunakan MATLAB. Pada MATLAB akan dilakukan pemfilteran secara software menggunakan filter eksponensial, setelah itu sinyal hasil pemfilteran akan dianalisis besar amplitudonya sehingga dapat diketahui jenis gerakan lengan yang dilakukan.

\subsection{Perancangan Peletakan Elektroda}

Peletakan elektroda yang tepat merupakan fungsi vital pada penelitian ini. Peletakan elektroda berpengaruh secara langsung terhadap sinyal otot yang dihasilkan. Pada pergerakan lengan terdapat dua otot yang berperan dalam melakukan gerakan, yaitu otot bisep dan otot trisep. Gerakan dasar yang bisa dilakukan oleh lengan yaitu gerakan ekstensi dan fleksi. Gerakan ekstensi adalah gerakan pada saat lengan dalam keadaan lurus. Sedangkan gerakan fleksi adalah gerakan pada saat lengan dalam keadaan menekuk (Chabbra, et al., 2012).

Pada gerakan ekstensi, otot trisep sedang berkontraksi sedangkan otot bisep relaksasi. Begitu juga sebaliknya, dalam gerakan fleksi, otot bisep yang berkontraksi dan otot trisep yang relaksasi. Jadi dapat disimpulkan bahwa kerja dari otot bisep dan trisep saling berkebalikan. Dalam penelitian ini pengukuran sinyal difokuskan hanya pada otot bisep saja. Sehingga nantinya akan didapatkan hasil sinyal kontraksi ketika gerakan fleksi dan sinyal relaksasi ketika gerakan ekstensi. Peletakan elektroda pada penelitian ini ditunjukkan pada Gambar 2. Pada gambar tersebut, dua elektroda diletakkan pada otot bisep dan satu elektroda lagi diletakkan pada pergelangan tangan yang digunakan sebagai elektroda referensi.

\subsection{Perancangan Penguat Instrumentasi}

Penguatan sinyal dilakukan oleh penguat instrumentasi. Penguatan ini tidak bisa dilakukan dengan op-amp sembarangan karena penguatan yang dilakukan harus memiliki kepresisian yang tinggi, maka dari itu diperlukan op-amp dengan nilai CMRR yang tinggi. IC OP07 dipilih karena memiliki nilai CMRR yang relatif tinggi yaitu $106 \mathrm{~dB}$, selain itu OP07 memang didesain untuk rangkaian instrumentasi medis. Besar penguatan dari IC OP07 dapat dihitung dengan menentukan besar nilai resistor $R_{1}, R_{3}, R_{4}$ dan $R_{6}$ pada rangkaian dengan menggunakan Persamaan (1). Rangkaian penguat instrumentasi ditunjukkan pada Gambar 3. Dengan menggunakan nilai penguatan $G$ sebesar $400 \mathrm{x}$, nilai $R_{l}$ sebesar $1 \mathrm{k} \Omega$, $R_{3}$ sebesar $3 \mathrm{k} \Omega$ dan $R_{4}$ sebesar $1 \mathrm{k} \Omega$, maka nilai dari $R_{6}$ didapat sebesar:

$$
\begin{aligned}
& \text { Gain }=\left(1+\frac{2 R_{1}}{R_{3}}\right) \frac{R_{6}}{R_{4}} \\
& 400=\left(1+\frac{2 \cdot 10^{3}}{3 \cdot 10^{3}}\right) \frac{R_{6}}{10^{3}} \\
& R_{6}=239,52 \cdot 10^{3} \Omega
\end{aligned}
$$

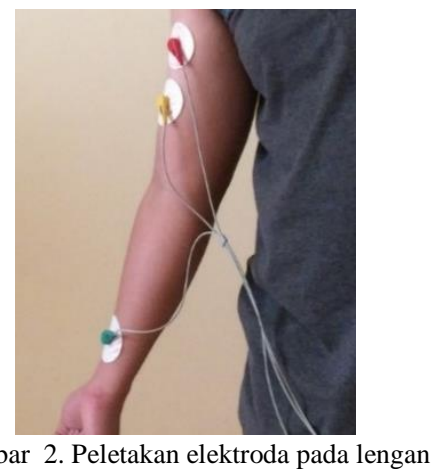




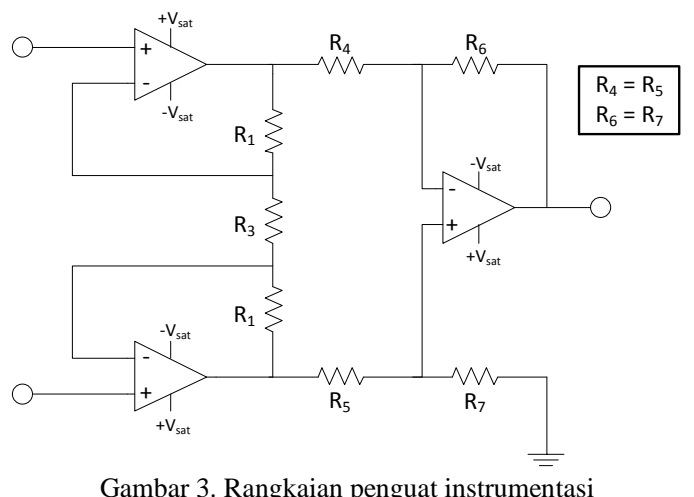

Nilai resistor yang paling mendekati nilai $239.52 \mathrm{k} \Omega$ adalah $250 \mathrm{k} \Omega$, maka resistor dengan nilai $250 \mathrm{k} \Omega$ digunakan dalam rangkaian ini sehingga penguatan yang didapat sebesar 416x.

\subsection{Perancangan High Pass Filter}

Dalam rangkaian EMG, sinyal otot memiliki rentang frekuensi yang lebar yaitu bisa mencapai ribuan Hz. Namun sinyal yang memiliki informasi penting hanya memiliki range frekuensi antara 1.5 sampai $5 \mathrm{~Hz}$. Oleh karena itu harus dirancang HPF yang memiliki frekuensi cut-off $1.5 \mathrm{~Hz}$. Rangkaian HPF yang digunakan dalam penelitian ini adalah HPF aktif orde 2, seperti yang ditunjukkan pada Gambar 4.

Besarnya nilai resistor dan kapasitor $R_{8}, R_{9}, C_{3}$ dan $C_{4}$ dapat dihitung dengan menggunakan Persamaan (2). Dengan menentukan nilai $R_{8}$ sebesar $100 \mathrm{k} \Omega, C_{3}$ sebesar $1 \mu \mathrm{F}$ dan $C_{4}$ sebesar $10 \mu \mathrm{F}$, maka didapatkan nilai $R_{9}$ sebesar:

$f_{c}=\frac{1}{2 \pi \sqrt{R_{8} R_{9} C_{3} C_{4}}}$

$$
1,5=\frac{1}{2 \cdot 3,14 \sqrt{100 \cdot 10^{3} \cdot R_{9} \cdot 10^{-6} \cdot 10 \cdot 10^{-6}}}
$$

$R_{9}=11,12 \cdot 10^{3} \Omega$

Karena nilai resistor $11.12 \mathrm{k} \Omega$ tidak tersedia, sehingga digunakan resistor dengan nilai $10 \mathrm{k} \Omega$ pada rangkaian ini. Dengan memasukkan nilai $R_{8}, R_{9}, C_{3}$ dan $C_{4}$ yang telah ditentukan, maka diperoleh nilai frekuensi cut-off rangkaian HPF sebesar $1.592 \mathrm{~Hz}$.

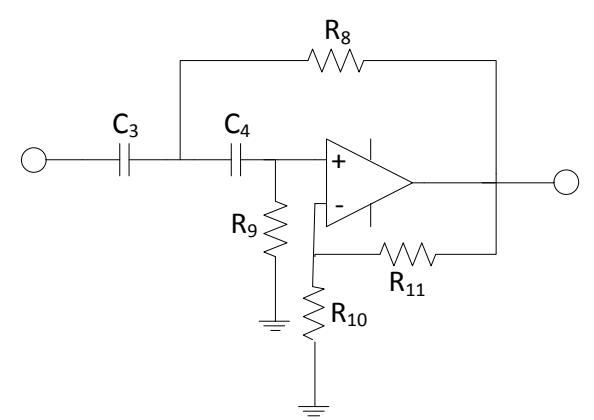

Gambar 4. Rangkaian high pass filter
Selain mengatur nilai frekuensi cut-off, pada rangkaian filter aktif juga diperlukan pengaturan nilai gain yang dibutuhkan oleh sistem. Besarnya penguatan rangkaian filter aktif dapat ditentukan dengan menggunakan Persamaan (3). Penguatan yang digunakan pada rangkaian ini adalah sebesar 3x, nilai $R_{11}$ sebesar $10 \mathrm{k} \Omega$, maka nilai dari $R_{10}$ didapat sebesar:

$\operatorname{Gain}(A v)=1+\frac{R_{11}}{R_{10}}$

$3=1+\frac{10.10^{3}}{R_{10}}$

$R_{10}=5 \cdot 10^{3} \Omega$

Dari perhitungan diatas didapatkan nilai dari $R_{10}$ sebesar $5 \mathrm{k} \Omega$.

\subsection{Perancangan Low Pass Filter}

Seperti pada penjelasan HPF, frekuensi sinyal otot dibatasi antara range $1.5 \mathrm{~Hz}$ sampai $5 \mathrm{~Hz}$. Oleh karena itu harus dirancang LPF yang memiliki frekuensi cut-off $5 \mathrm{~Hz}$. Rangkaian LPF yang digunakan dalam penelitian ini adalah LPF aktif orde 2, seperti yang ditunjukkan pada Gambar 5.

Besarnya nilai resistor dan kapasitor $R_{12}, R_{13}, C_{5}$ dan $C_{6}$ dapat dihitung dengan menggunakan Persamaan (4). Dengan menentukan nilai $R_{12}$ sebesar $100 \mathrm{k} \Omega, C_{5}$ sebesar $1 \mu \mathrm{F}$ dan $C_{4}$ sebesar $1 \mu \mathrm{F}$, maka didapatkan nilai $R_{13}$ sebesar:

$f_{C}=\frac{1}{2 \pi \sqrt{R_{12} R_{13} C_{5} C_{6}}}$

$$
5=\frac{1}{2 \cdot 3,14 \sqrt{100 \cdot 10^{3} \cdot R_{9} \cdot 10^{-6} \cdot 10^{-6}}}
$$

$R_{13}=10 \cdot 10^{3} \Omega$

Dari perhitungan diatas, didapatkan nilai $R_{13}$ sebesar $10 \mathrm{k} \Omega$. Dengan memasukkan nilai $R_{12}, R_{13}, C_{5}$ dan $C_{6}$ yang telah ditentukan, maka diperoleh nilai frekuensi cut-off rangkaian LPF sebesar $5.04 \mathrm{~Hz}$.

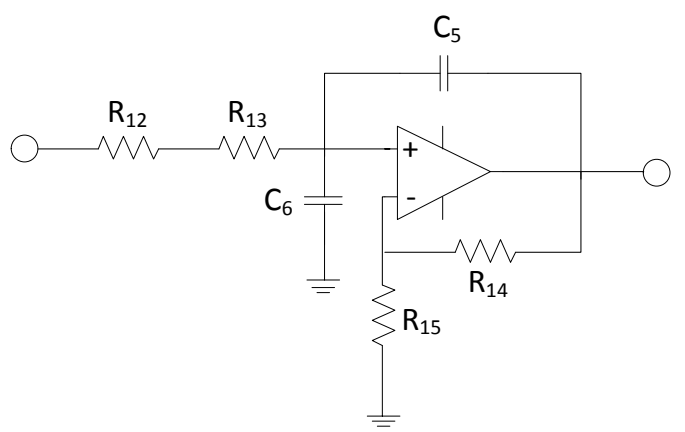

Gambar 5. Rangkaian low pass filter 
Selain mengatur nilai frekuensi cut-off, pada rangkaian filter aktif juga diperlukan pengaturan nilai gain yang dibutuhkan oleh sistem seperti pada penjelasan perancangan HPF. Penguatan yang digunakan pada rangkaian ini adalah sebesar 3x, nilai $R_{15}$ sebesar $10 \mathrm{k} \Omega$, maka nilai dari $R_{14}$ didapat sebesar $5 \mathrm{k} \Omega$.

\subsection{Perancangan Keseluruhan Rangkaian}

Setelah menentukan nilai dari masing-masing rangkaian yang diperlukan, maka langkah selanjutnya adalah merangkai seluruh rangkaian tersebut menjadi sebuah rangkaian utuh. Sesuai dengan diagram blok pada Gambar 1, maka sinyal dari elektroda menjadi masukan untuk rangkaian instrumentasi, kemudian dari rangkaian instrumentasi dilakukan pemfilteran dengan menggunakan rangkaian HPF dan LPF. Rangkaian keseluruhan pengkondisi sinyal ditunjukkan pada Gambar 6.

\subsection{Perancangan Filter Eksponensial}

Sinyal keluaran dari rangkaian pengkondisi sinyal menjadi masukan untuk filter eksponensial yang diproses dengan menggunakan MATLAB. Filter eksponensial merupakan filter rekursif linier yang dapat digunakan untuk mengurangi noise yang terdapat dalam sebuah sinyal, dalam hal ini adalah sinyal EMG. Penggunaan filter eksponensial pada penelitian ini yaitu betujuan untuk mendapatkan hasil sinyal EMG yang lebih akurat. Pemfilteran ini perlu dilakukan karena sinyal hasil pengkondisian sinyal masih terdapat noise yang mempengaruhi nilai amplitudo dari sinyal tersebut. Persamaan dari filter eksponensial ditunjukkan pada Persamaan (5) (Zhang, et al., 2013).

$y_{(n)}=w * x_{(n)}+(1-w) * y_{(n-1)}$

dimana

$y_{(n)} \quad=$ keluaran filter eksponensial

$y_{(n-1)}=$ keluaran filter eksponensial sebelumnya

$x_{(n)} \quad=$ masukan filter eksponensial

$w \quad=$ koefisien pembobotan filter

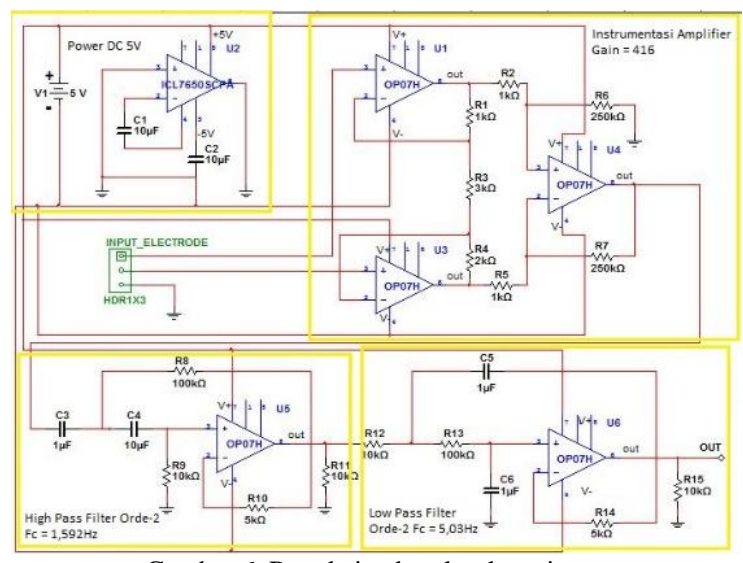

Gambar 6. Rangkaian keseluruhan sistem

\subsection{Penentuan Jenis Gerakan Lengan}

Jenis gerakan lengan yang dirancang untuk dideteksi pada penelitian ini berjumlah lima gerakan. Kelima gerakan tersebut yaitu gerakan lengan lurus, gerakan lengan membentuk sudut $45^{\circ}, 90^{\circ}, 135^{\circ}$ dan $180^{\circ}$. Masing-masing gerakan lengan terlebih dahulu diakuisisi datanya sebagai data latih sebanyak 10 kali percobaan. Kesepuluh data latih ini kemudian dihitung nilai rata-rata amplitudonya. Nilai rata-rata tersebut akan digunakan untuk menentukan nilai range amplitudo masing-masing jenis gerakan saat dilakukan pengujian. Range amplitudo untuk masingmasing jenis gerakan dapat dihitung berdasarkan Persamaan (6).

$r=\bar{x} \pm 0.1$

dimana

$r \quad=$ range amplitudo

$\bar{x} \quad=$ rata-rata amplitudo

\section{PENGUJIAN DAN ANALISIS}

Pengujian pada penelitian ini dibagi menjadi tiga tahap. Pada pengujian pertama akan dilakukan pengujian untuk menentukan nilai koefisien filter $(w)$ yang paling sesuai dengan sistem yang telah dirancang. Setelah didapatkan nilai $w$ yang sesuai, maka dilakukan pengujian kedua. Pengujian kedua dilakukan untuk menganalisis besar amplitudo dari masing-masing sinyal gerakan lengan yang diujikan. Dimana nilai amplitudo ini nantinya akan digunakan sebagai data latih untuk menentukan range amplitudo masing-masing gerakan. Sedangkan untuk pengujian terakhir dilakukan untuk mengetahui akurasi sistem. Pengujian dilakukan dengan melihat kesesuaian keluaran sistem berdasarkan jenis gerakan lengan yang diujikan.

Pada pengujian pertama, pengujian dilakukan dengan menggunakan tiga nilai $w$ yang berbeda, yaitu $0.1,0.4$ dan 0.7. Prosedur pada pengujian ini adalah dengan menempatkan dua elektroda pada otot bisep dan satu buah elektroda di pergelangan tangan, yang digunakan sebagai elektroda referensi. Sinyal output dari elektroda digunakan sebagai sinyal masukan pada rangkaian pengkondisi sinyal yang telah dirancang, berturut-turut yaitu rangkaian penguat instrumentasi, HPF dan LPF. Setelah itu sinyal keluaran dari LPF dihubungkan dengan perangkat keras akuisisi data dan diproses menggunakan MATLAB. Pada MATLAB akan dilakukan pemfilteran menggunakan filter eksponensial. Penempatan elektroda untuk pengujian pertama ditunjukkan pada Gambar 7. Pada gambar tersebut dapat dilihat bahwa gerakan lengan yang diujikan adalah gerakan lengan $180^{\circ}$. Hal ini dikarenakan pada gerakan lengan $180^{\circ}$, otot bisep berkontraksi maksimal sehingga perubahan sinyal maupun noise 


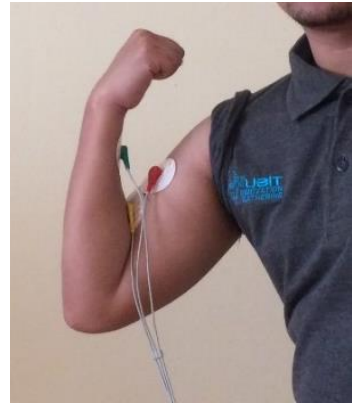

Gambar 7. Penempatan elektroda pada pengujian pertama

mudah untuk diamati. Hasil dari pengujian ini ditunjukkan pada Gambar 8. Dimana untuk sinyal berwarna biru merupakan sinyal asli EMG, sedangkan sinyal berwarna merah merupakan sinyal hasil dari pemfilteran menggunakan filter eksponensial.

Dari data hasil pengujian yang telah dilakukan, dapat diketahui bahwa filter eksponensial mampu untuk mengurangi noise yang ada pada sinyal EMG. Untuk nilai $w=0.1$, sinyal yang terfilter memiliki bentuk sinyal yang relatif berbeda dengan sinyal aslinya. Sementara untuk nilai $w=0.4$, bentuk sinyal relatif sama dengan sinyal asli dengan mengurangi noise yang ada pada sinyal tersebut. Sedangkan untuk nilai $w=0.7$, sinyal hasil filter eksponensial masih memiliki cukup banyak noise jika dibandingkan dengan sinyal aslinya. Sehingga dapat disimpulkan bahwa nilai $w$ yang paling optimal dalam sistem ini adalah 0.4.

Pada pengujian kedua, pengujian dilakukan untuk mengetahui besar amplitudo masing-masing gerakan yang telah ditentukan sebelumnya. Gerakan tersebut meliputi gerakan lengan lurus, gerakan lengan membentuk sudut $45^{\circ}, 90^{\circ}, 135^{\circ}$ dan $180^{\circ}$. Pengujian dilakukan sebanyak 10 kali untuk masingmasing gerakan. Berdasarkan pengujian pertama, maka dalam pengujian ini digunakan nilai $w=0.4$. Untuk prosedur akuisisi datanya sama dengan prosedur pada pengujian pertama. Hasil pengujian nilai amplitudo untuk masing-masing gerakan lengan ditunjukkan pada Tabel 1.

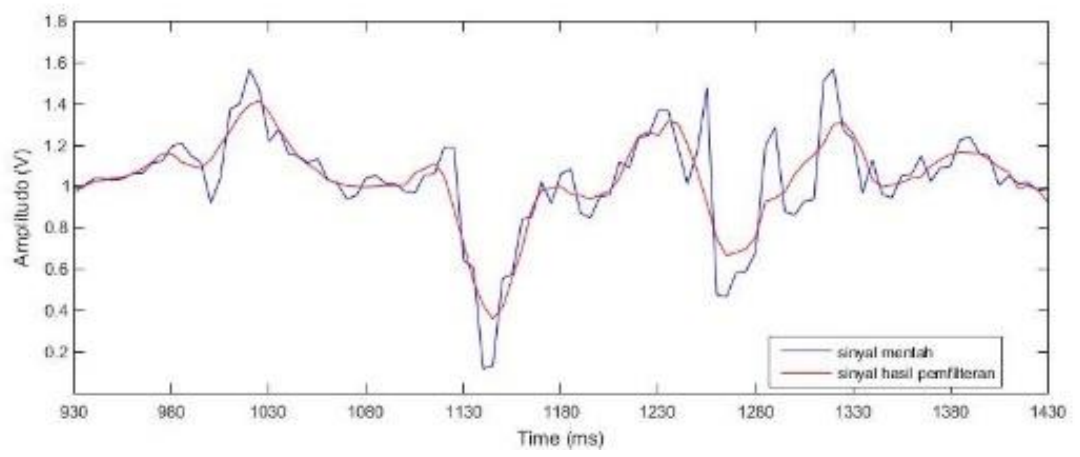

(a)

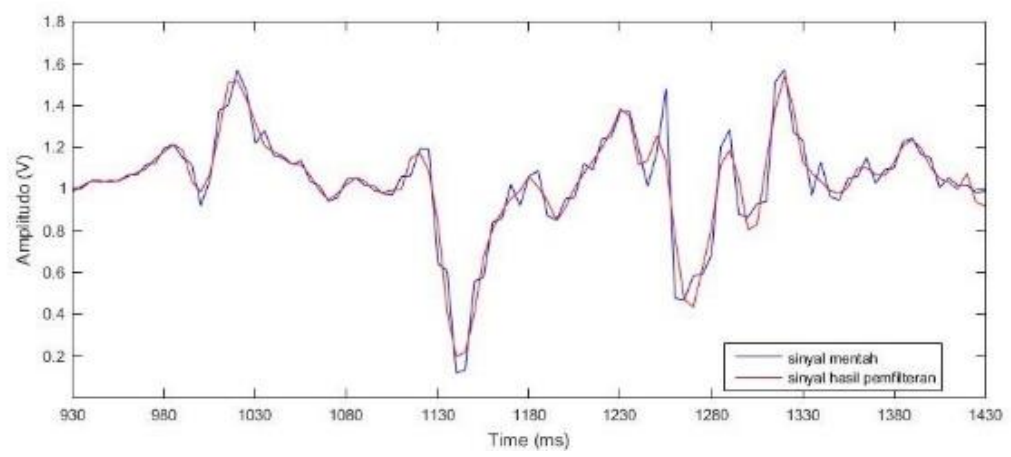

(b)

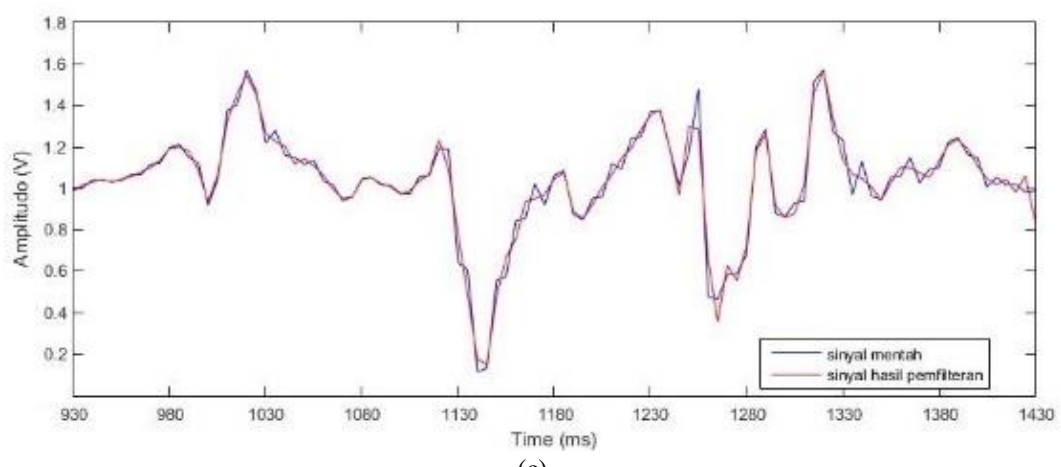

(c)

Gambar 8. Sinyal pengujian masing-masing nilai $w:$ (a) $w=0.1$; (b) $w=0.4$; (c) $w=0.7$ 
Tabel 1. Nilai amplitudo pengujian masing-masing gerakan lengan

\begin{tabular}{cccccc}
\hline \multirow{2}{*}{ pengujian } & \multicolumn{5}{c}{ amplitudo (V) } \\
\cline { 2 - 5 } & lengan lurus & lengan 45 $^{\circ}$ & lengan 90 $^{\circ}$ & lengan 135 $^{\circ}$ & lengan180 $^{\circ}$ \\
\hline 1 & 0.168 & 0.535 & 1.026 & 1.313 & 1.662 \\
2 & 0.117 & 0.637 & 0.954 & 1.275 & 1.717 \\
3 & 0.125 & 0.517 & 0.998 & 1.367 & 1.565 \\
4 & 0.169 & 0.646 & 1.147 & 1.416 & 1.666 \\
5 & 0.181 & 0.555 & 1.065 & 1.293 & 1.791 \\
6 & 0.239 & 0.596 & 1.164 & 1.336 & 1.597 \\
7 & 0.176 & 0.498 & 0.974 & 1.374 & 1.634 \\
8 & 0.127 & 0.639 & 0.985 & 1.421 & 1.712 \\
9 & 0.138 & 0.713 & 0.976 & 1.534 & 1.636 \\
10 & 0.218 & 0.543 & 1.198 & 1.339 & 1.486 \\
Rata-Rata & 0.166 & 0.588 & 1.049 & 1.367 & 1.647 \\
\hline
\end{tabular}

Dari hasil pengujian yang telah dilakukan, didapatkan nilai amplitudo rata-rata dari gerakan lengan lurus sebesar $0.166 \mathrm{~V}$, gerakan lengan $45^{\circ}$ sebesar $0.588 \mathrm{~V}$, gerakan lengan $90^{\circ}$ sebesar $1.049 \mathrm{~V}$, gerakan lengan $135^{\circ}$ sebesar $1.367 \mathrm{~V}$ dan gerakan lengan $180^{\circ}$ sebesar $1.647 \mathrm{~V}$. Dapat dianalisis bahwa semakin besar sudut gerakan lengan yang dilakukan, maka semakin besar pula nilai rata-rata amplitudonya. Hal ini dipengaruhi langsung oleh kontraksi yang terjadi pada otot bisep. Ketika gerakan lengan lurus, otot bisep dalam keadaan relaksasi. Sehingga didapatkan nilai amplitudo yang mendekati nilai nol. Semakin besar sudut yang dilakukan oleh lengan, maka otot bisep akan semakin berkontraksi. Kontraksi maksimal terjadi ketika gerakan lengan $180^{\circ}$, sehingga didapatkan nilai amplitudo yang paling besar dibandingkan dengan gerakan lengan yang lainnya. Nilai rata-rata amplitudo yang didapatkan pada pengujian kedua ini, digunakan sebagai dasar untuk menentukan range amplitudo masing-masing gerakan pada pengujian terakhir.

Pada pengujian terakhir akan diamati akurasi sistem dalam menentukan jenis gerakan lengan yang dilakukan. Pengujian ini dilakukan dengan cara menggerakkan lengan sesuai dengan kelima gerakan yang telah ditentukan sebelumnya secara acak, sebanyak 15 kali pengujian. Amplitudo yang dihasilkan dari masing-masing gerakan tersebut akan dibandingkan dengan range amplitudo yang didapatkan dari data latih pengujian kedua. Jenis gerakan ditentukan sesuai dengan dimana nilai amplitudo gerakan tersebut berada pada salah satu nilai range amplitudo. Nilai range amplitudo masingmasing gerakan ditunjukkan pada Tabel 2. Nilai range ini ditentukan berdasarkan Persamaan (6). Sedangkan untuk hasil pengujian akurasi sistem ditunjukkan pada Tabel 3.

Tabel 2. Nilai range amplitudo masing-masing gerakan lengan

\begin{tabular}{cc}
\hline jenis gerakan & range amplitudo $(\mathbf{V})$ \\
\hline lengan lurus & $0.066-0.266$ \\
lengan $45^{\circ}$ & $0.488-0.688$ \\
lengan $90^{\circ}$ & $0.949-1.149$ \\
lengan $135^{\circ}$ & $1.267-1.467$ \\
lengan $180^{\circ}$ & $1.547-1.747$ \\
\hline
\end{tabular}

Dari data hasil pengujian pada Tabel 3, terdapat ketidaksesuaian hasil identifikasi sistem pada pengujian nomor 6 dan 11. Dengan adanya dua data yang tidak sesuai dengan identifikasi sistem dari total 15 data pengujian, maka didapatkan tingkat akurasi sistem dalam menentukan jenis gerakan lengan adalah sebesar $86.67 \%$.

\section{KESIMPULAN}

Pada penelitian ini ditawarkan sebuah sistem pengkondisi sinyal EMG yang bertujuan untuk mendapatkan hasil pembacaan sinyal EMG yang akurat untuk masing-masing gerakan lengan. Sistem terdiri dari rangkaian pengkondisi sinyal secara hardware maupun pemfilteran secara software. Rangkaian pengkondisi sinyal yang dirancang terdiri dari rangkaian penguat instrumentasi, HPF dan LPF. Sedangkan untuk pemfilteran secara software dilakukan dengan menggunakan filter eksponensial yang diproses pada MATLAB. Dari hasil pengujian yang telah dilakukan, filter eksponensial mampu untuk mengurangi noise yang terdapat pada sinyal EMG. Nilai koefisien filter $(w)$ yang paling optimal digunakan pada sistem ini adalah 0.4. Nilai tersebut digunakan untuk pengujian nilai amplitudo masingmasing gerakan lengan. Dimana didapatkan nilai amplitudo rata-rata untuk gerakan lengan lurus yaitu

\begin{tabular}{cccc}
\multicolumn{4}{c}{ Tabel 3. Pengujian akurasi sistem } \\
\hline pengujian & $\begin{array}{c}\text { amplitudo } \\
(\mathbf{V})\end{array}$ & $\begin{array}{c}\text { gerakan yang } \\
\text { dilakukan }\end{array}$ & $\begin{array}{c}\text { identifikasi } \\
\text { sistem }\end{array}$ \\
\hline 1 & 0.492 & lengan $45^{\circ}$ & lengan $45^{\circ}$ \\
2 & 0.239 & lengan lurus & lengan lurus \\
3 & 0.956 & lengan $90^{\circ}$ & lengan $90^{\circ}$ \\
4 & 1.337 & lengan $135^{\circ}$ & lengan $135^{\circ}$ \\
5 & 0.217 & lengan lurus & lengan lurus \\
6 & 1.036 & lengan $135^{\circ}$ & lengan $90^{\circ}$ \\
7 & 1.741 & lengan $180^{\circ}$ & lengan $180^{\circ}$ \\
8 & 0.596 & lengan $45^{\circ}$ & lengan $45^{\circ}$ \\
9 & 1.008 & lengan $90^{\circ}$ & lengan $90^{\circ}$ \\
10 & 1.636 & lengan $180^{\circ}$ & lengan $180^{\circ}$ \\
11 & 0.559 & lengan lurus & lengan $45^{\circ}$ \\
12 & 1.093 & lengan $90^{\circ}$ & lengan $90^{\circ}$ \\
13 & 0.552 & lengan $45^{\circ}$ & lengan $45^{\circ}$ \\
14 & 1.411 & lengan $135^{\circ}$ & lengan $135^{\circ}$ \\
15 & 1.692 & lengan $180^{\circ}$ & lengan $180^{\circ}$ \\
\hline
\end{tabular}


$0.166 \mathrm{~V}$, gerakan lengan $45^{\circ}$ sebesar $0.588 \mathrm{~V}$, gerakan lengan $90^{\circ}$ sebesar $1.049 \mathrm{~V}$, gerakan lengan $135^{\circ}$ sebesar $1.367 \mathrm{~V}$ dan gerakan lengan $180^{\circ}$ sebesar 1.647 V. Nilai rata-rata amplitudo ini digunakan untuk menentukan range amplitudo pada pengujian akurasi sistem. Dari 15 kali pengujian, terdapat dua kesalahan identifikasi oleh sistem. Sehingga didapatkan nilai akurasi sistem dalam menentukan jenis gerakan lengan sebesar $86.67 \%$.

\section{DAFTAR PUSTAKA}

AURICCHIO, F., FERRARA, A., LANZARONE, E., MORGANTI, S. \& TOTARO, P., 2017. A Regression Method Based on Noninvasive Clinical Data to Predict the Mechanical Behavior of Ascending Aorta Aneurysmall Tissue. IEEE Transactions on Biomedical Engineering, Vol. 64, No. 11, pp.2607-2617.

CHHABRA, A. \& ANDREISEK, G., 2012. Magnetic Resonance Neurography. New Delhi: Medical Publishers.

CHOWDURRY, R.H., REAZ, M.B.I., ALI, M.A.B.M., BAKAR, A.A.A., CHELLAPPAN, K. \& CHANG, T.G., 2013. Surface Electromyography Signal Processing and Classification Technique. Sensors, pp.12431-12466.

ISKANDAR, P., 2012. Hukum HAM Internasional: Sebuah Pengantar Konstekstual. Cianjur: IMR Press.

HASANAH, U., RESITA, L., PRATAMA, A. \& CHOLISSODIN, I., 2016. Perbandingan Metode SVM, Fuzzy-KNN dan BDT-SVM Untuk Klasifikasi Detak Jantung Hasil Elektrokardiografi. Jurnal Teknologi Informasi dan Ilmu Komputer (JTIIK), Vol. 3, No.3, pp.201-207.

JUMENO, D. \& SETIANSYAH, T., 2009. Tangan Buatan Berteknologi Robot TB-1 Untuk Penyandang Cacat. Bandung: Prosiding Seminar Nasional Ergonomi dan K3.

MUCHLIS, I., MAULANA, R. \& FITRIYAH, H., 2017. Implementasi Pengenalan Pergerakan Bola Mata Menggunakan Elektroda Dengan Eksponensial Filter. Jurnal Pengembangan Teknologi Informasi dan Ilmu Komputer, Vol. 2, No. 9, pp.3093-3102.

RAJESH, A.N., CHANDRALINGAM, S., ANJANEYU, T. \& SATYANARAYANA, K., 2014. EOG Controlled Motorized Wheelchair for Disabled Person. International Journal of Mechanical and Materials Engineering, Vol. 8, No. 5, pp.302-305.

RECTOR, K., 2018. Enhancing Accessibility and Engagement for Those with Disabilities.
IEEE Pervasive Computing, Vol. 17, No. 1, pp.9-12.

SANTAGATI, G.E. \& MELODIA, T., 2017. Experimental Evaluation of Impulsive Ultrasonic Intra-Body Communications for Implantable Biomedical Device. IEEE Transactions on Mobile Computing, Vol. 16, No. 2, pp.367-380.

SEMMLOW, J.L., 2004. Biosignal and Biomedical Image Processing: MATLAB-Based Applications. New York: Marcel Dekker.

SHARMILA, K. \& SARATH, T.V., 2016. EMG Controlled Low Cost Prostethic Arm. IEEE Distributed Computing VLSI, Electrical Circuit and Robotics, pp.169-172.

ZHANG, L., DENG, K., WANG, H.Q. \& LUO, M.K., 2013. Exponential Filter-Based Delay Estimation Algorithm for Active Systems in the Presence of Multi-Targets. IET Radar, Sonar and Navigation, Vol. 7, No. 3, pp.287294. 